\title{
Climate Change and $\mathrm{CO}_{2}$ Removal from the Atmosphere
}

\author{
Roelof Dirk Schuiling \\ Institute of Geosciences, Utrecht University, Utrecht, The Netherlands \\ Email: Schuiling@geo.uu.nl \\ Received 18 March 2014; revised 18 April 2014; accepted 25 April 2014 \\ Copyright @ 2014 by author and Scientific Research Publishing Inc. \\ This work is licensed under the Creative Commons Attribution International License (CC BY). \\ http://creativecommons.org/licenses/by/4.0/

(c) (i) Open Access

\begin{abstract}
Several methods have been proposed in recent years to counteract climate change and ocean acidification by removing $\mathrm{CO}_{2}$ from the atmosphere (Carbon Dioxide Removal). The most versatile and widely applicable of these methods is enhanced weathering of olivine, which is capable of removing billions of tons of $\mathrm{CO}_{2}$ from the atmosphere at moderate cost compared to the high cost of Carbon Capture and Storage (CCS). Despite its disadvantages, CCS is still the favored solution of many governments. Many misunderstandings of the potential of enhanced weathering persist. This paper addresses some of these misunderstandings, mainly caused by models which ignore established facts.
\end{abstract}

\section{Keywords}

\section{Mineral Carbonation, Olivine Concept, Failing Models}

\section{Introduction}

Each year the Earth emits in the order of $0.5 \mathrm{Gt}$ of $\mathrm{CO}_{2}$, mainly by volcanoes. If all that $\mathrm{CO}_{2}$ remained in the atmosphere, it would require little time, geologically speaking, to create an atmosphere dominated by $\mathrm{CO}_{2}$. Apparently there is an efficient process by which it is removed again and safely stored. That process is the weathering of basic silicates, mainly Mg- and Ca-silicates. If we take olivine, for example, the most common mineral on Earth, its weathering is as follows:

$$
\mathrm{Mg}_{2} \mathrm{SiO}_{4}+4 \mathrm{CO}_{2}+4 \mathrm{H}_{2} \mathrm{O} \rightarrow 2 \mathrm{Mg}^{2+}+4 \mathrm{HCO}_{3}^{-}+4 \mathrm{H}_{4} \mathrm{SiO}_{4} \text {. }
$$

The magnesium and calcium bicarbonate solutions that are formed in such reactions are carried by rivers to the sea, where corals, shellfish and foraminifera convert them to limestones and dolomites. These are the sustainable $\mathrm{CO}_{2}$ stores of the Earth. This weathering process has kept the $\mathrm{CO}_{2}$ levels of the atmosphere in check 
during the whole history of the Earth. There have been variations, both in volcanic activity as in the exposure of suitable rocks, but the weathering process has a built-in negative feedback system, so the system moves automatically to some state of equilibrium. The negative feedback works are as follows: when the $\mathrm{CO}_{2}$ levels in the atmosphere rise, soil solutions become more acidic and weathering becomes more active, so more $\mathrm{CO}_{2}$ is captured.

Humankind is now causing a spike in $\mathrm{CO}_{2}$ emissions by burning in a few hundred years the fossil fuels that have formed during hundreds of millions of years. Present emission of $\mathrm{CO}_{2}$ far exceeds the normal emission by volcanoes, and the weathering process cannot cope with this sudden rise. By increasing the rate of weathering, we can achieve a new balance between input and output. Basically this means that we must remove the weathering crust on top of many dunite massifs (dunites are rocks with more than $90 \%$ olivine, they occur in many countries on all continents). This first step will already reactivate the weathering potential of these massifs, but it will be necessary to also mine the olivine in a number of locations, strategically distributed over the globe to keep transport lines short to the points of use. After mining, the olivine is milled, and the resulting olivine sand is spread over land, beaches and shallow, energetic seas. This is the concept of enhanced weathering, which has brought forth a lot of misunderstanding, because most people are unfamiliar with geological processes. Another factor is that people working on CCS see other solutions as a threat to their work (and income), so any argument is used to show that enhanced weathering does not work. CCS is wrongly called geological storage, because it just borrows the storage box from geological formations and has no counterpart in geological processes, whereas weathering is the main natural process which takes care of geological storage of $\mathrm{CO}_{2}$ [1].

\section{Examples of Misunderstanding}

A common misleading statement is that olivine rocks are dangerous because they contain asbestos. The truth is that only some olivine massifs contain chrysotile asbestos, but this is rare, and evidently no mining company will run the risk of selling asbestos-containing dunites, because they would quickly lose their clients. There are plenty of asbestos-free dunite massifs around to choose from.

A second argument that is often heard is that dunites (or olivine rocks in general) are dangerous because they contain high levels of nickel. It is true that these rocks contain more nickel than most other rock-types, but that argument doesn't make these rocks dangerous. From a survey of the geological maps of many countries it can be concluded that olivine-rich rocks occupy more than 1 million $\mathrm{km}^{2}$ on Earth. Hundreds of millions of people live in these areas already for many generations, they grow their crops, they graze their animals, and they drink its water, without any negative consequences.

A third argument that is often heard is that the weathering of olivine is a very slow process, and that it's weathering in nature proceeds even slower than under controlled conditions in the laboratory with the exclusion of biotic factors. Weathering is indeed a relatively slow process, but olivine is the fastest weathering common silicate, and weathering in nature proceeds much faster than in a sterile laboratory. It is relatively easy to determine an average rate of weathering for olivine in large massifs under tropical conditions. If the olivine massif is covered by 100 meter of laterite (laterite is its weathering residue), which is virtually free of magnesium and silica that make up $90 \%$ of the dunite [2], this means that 100 meter of laterite represents 1000 meter of weathered dunite (and this is a low estimate because it assumes that all the other elements in the dunite have been perfectly immobile). Dividing 1000 meter by the radiometric age of the dunite massif gives the average weathering rate over several hundred million years. The real rate of weathering when the rock was not yet covered with a thick laterite crust must have been higher, because a thick weathering crust diminishes the interaction between the fresh rock and the $\mathrm{CO}_{2}$ and water from the atmosphere. Recently weathering rates of up to $2.5 \mathrm{~mm}$ /year were measured in the mountains of South Island, New Zealand [3]. This high number includes the denudation rate. The chemical weathering rate was about $0.8 \mathrm{~mm} /$ year, but that is still very high. For the time-averaged weathering rate of several dunite massifs the numbers are in the order of at least 10 to 20 micron per year, whereas under comparable conditions of $\mathrm{pH}$ and temperature the rate of weathering in the laboratory is around 1 micron per year. This shows the importance of biotic factors like lichens, soil bacteria and mycorrhizal fungi. Higher plants live in symbiosis with mycorrhizal fungi that secrete a range of organic acids in which the soil minerals dissolve [4]. The liberated mineral nutrients are taken up by the plants that "reward" the fungi by supplying them with sugar.

For the climate, it is not important that the olivine should weather very rapidly. When olivine grains that are spread over a field take a few years to weather, that is good enough, it is not necessary to add expensive tech- 
nologies like autoclaves to achieve rapid reaction rates [5].

\section{Misleading Models}

In [6] a detailed description of the potential and the limits of enhanced olivine weathering for $\mathrm{CO}_{2}$ removal is presented. Their model, however, does not consider biotic effects. A consequence of this is that their supposed limit imposed by silica saturation has no meaning in the real world. Plants, both on land as well as in the water need silica, in particular wet grasses (bamboo, rice, sugar cane, reeds) and certain types of plankton (diatoms). They gobble up any silica that is around, so associated waters never reach silica saturation, the more so because at ambient conditions, quartz does not precipitate and amorphous silica requires much higher silica concentrations before it precipitates. This means in practice, that the solubility of quartz is only a theoretical limit to $\mathrm{CO}_{2}$ capture by enhanced weathering of olivine, and is irrelevant in nature. This was particularly evident in the mining wastes of a former asbestos mine in British Columbia [7]. Weathering of the serpentinitic mining wastes rapidly produces a range of magnesium carbonate minerals, and the silica- rich water is partly left in the mine pit, without leading to silica precipitation. Diatoms, however, thrive in that mine pit lake [8] (Figure 1). This shows how dangerous it is to present theoretical models as a realistic picture of a process, when a major factor is not taken into account.

A similar situation is encountered in the model of Hangx and Spiers [9], describing what they see as problems when olivine grains are spread on beaches to capture $\mathrm{CO}_{2}$ and counteract ocean acidification. According to them, spreading olivine grains on beaches could not work within a reasonable time unless the grains would be milled to micron size at very high cost. According to their calculations normal sand-sized olivine would take 700 to 2100 years to dissolve. They also predict serious problems from the formation of a silica-rich passivating layer on the grains that would halt the reaction. If real, these would indeed be serious objections against the olivine concept, but fortunately they only hold in an imaginary world, where water does not move, and mineral grains stay in a fixed position on the beach for 2100 years, despite surf, waves, currents or storms. The authors have overlooked the fact that grains on the beach are continually milled by nature in the surf. This is a fundamental flaw of the model, which undermines their conclusions. It would have saved them a lot of work, if they had just asked themselves the simple question "Why are Grains on the Beach Rounded?"

It is, because grains tumble around in the surf, they collide, they abrade each other (Figure 2), resulting in myriads of micron sized olivine slivers that weather very fast [10]. So, to answer their objections:

- Extreme milling of olivine to micron size at high cost is a waste of money and energy. It happens automatically in the surf, which is the largest ball mill on Earth, and is free of charge.

- The formation of a passivating layer on the olivine grains is impossible, because if such layers would form, they would immediately be scraped off in the next wave.

Although their paper is widely cited, none of the readers, nor the reviewers seem to have noticed the fundamental flaw in the model. Apparently, a beautiful model makes people blind for the simple reality.

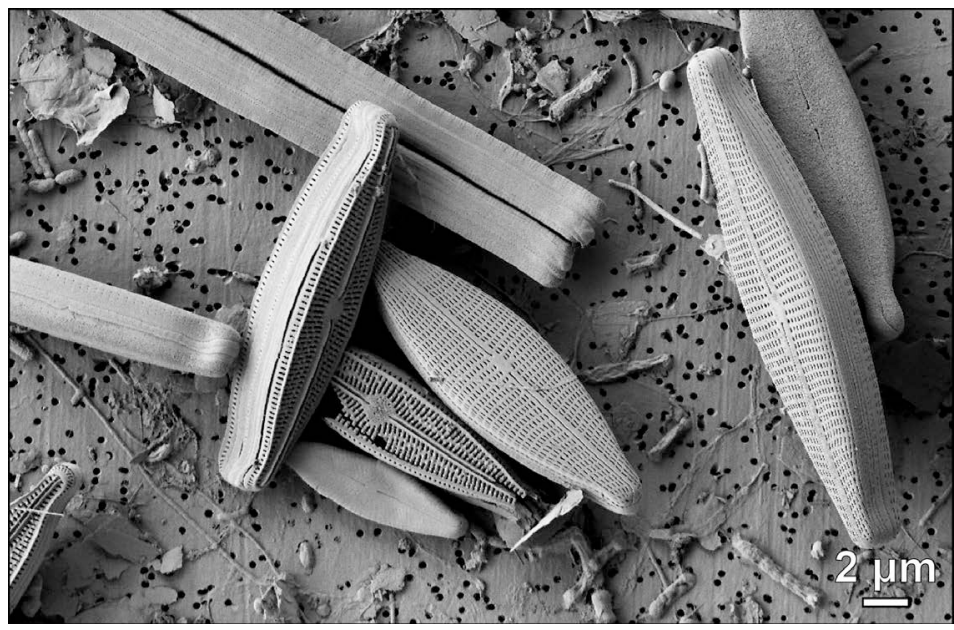

Figure 1. Diatoms from the mine pit lake of a former asbestos mine. 

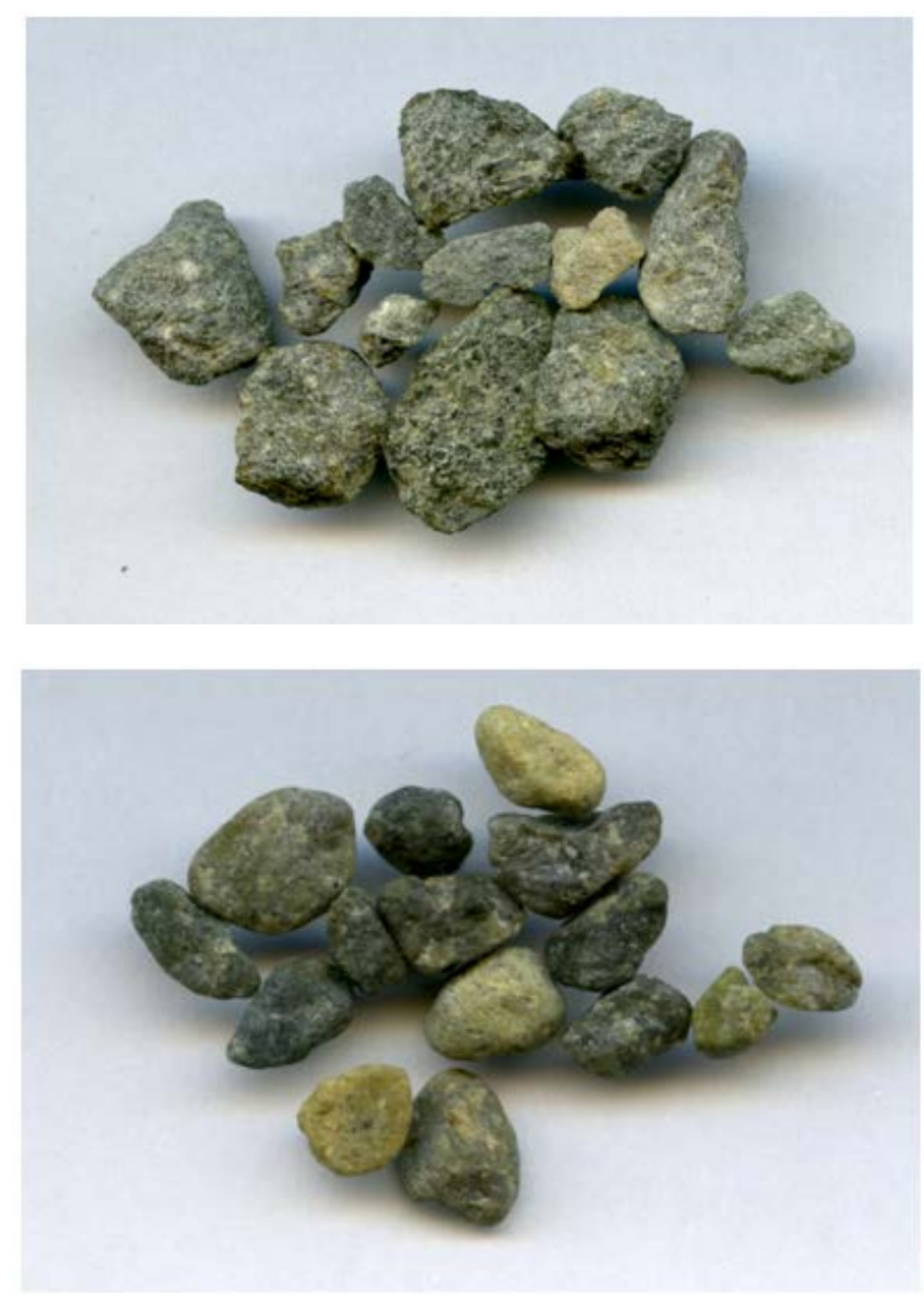

Figure 2. Before the experiment, the olivine grit is angular and rough (top). After a few days of quiet rotation the grains are rounded and polished (bottom).

\section{Conclusion}

Lack of understanding of geological processes leads to a number of false assumptions regarding enhanced weathering as a major tool against climate change and ocean acidification. There is a dangerous tendency in science to assume that models are the final goal, and to sanctify their results. Many people also seem to be intent to show that solutions aimed to solve major problems cannot work. A critical attitude is welcome in science, provided it goes hand in hand with a sound dose of self-criticism.

\section{Acknowledgments}

I wish to thank Ian Power for providing the picture of the diatoms in the mine pit of a former asbestos mine, and for correcting my original draft.

\section{References}

[1] Schuiling, R.D. (2009) Real Geological Storage of $\mathrm{CO}_{2}$. Greenhouse Issues No. 93, 17-18.

[2] Golightly, J.P. (1981) Nickeliferous Laterite Deposits. Economic Geology, 75th Anniversary Volume, 710-735.

[3] Larsen, I.J., Almond, P.C., Ege, A., Stone, J.O., Montgomery, D.R. and Malcolm, B.(2014) Rapid Soil Production and 
Weathering in the Western Alps, New Zealand. Science, 343, 637-643. http://dx.doi.org/10.1126/science.1244908

[4] Van Schöll, L., Kuyper, Th.W., Smits, M.M., Landeweert, R., Hoffland, E. and Van Bremen, N. (2008) Rock-Eating Mycorrhizas: Their Role in Plant Nutrition and Biogeochemical Cycles. Plant Soil, 303, 35-47. http://dx.doi.org/10.1007/s11104-007-9513-0

[5] Schuiling, R.D., Tickell, O. and Wilson, S.A. (2011) Climate Change and the KISS Principle. Poster presented at the 2011 Goldschmidt Conference in Prague.

[6] Köhler, P., Hartmann, J. and Wolf-Gladrow, D.A. (2010) The Geoengineering Potential of Artificially Enhanced Silicate Weathering of Olivine. Proceedings of the National Academy of Sciences, 147, 20228-20233. http://dx.doi.org/10.1073/pnas.1000545107

[7] Wilson, S.A., Dipple, G.M., Power, I.M., Thom, J.M., Anderson., R.G., Raudsepp, M., Gabites, J.E. and Southam, G. (2009) Carbon Dioxide Fixation within Mine Waste of Ultramafic Hosted Ore Deposits: Examples from the Clinton Creek and Cassiar Chrysotile Deposits, Canada. Economic Geology, 104, 95-112. http://dx.doi.org/10.2113/gsecongeo.104.1.95

[8] Power, I.M., Wilson, S.A., Dipple, G.M. and Southam, G. (2011) Modern Carbonate Microbialites from an Asbestos Open Pit Pond, Yukon, Canada. Geobiology, 9, 180-195.

[9] Hangx, S.J.T. and Spiers, C.J. (2009) Coastal Spreading of Olivine to Control Atmospheric $\mathrm{CO}_{2}$ Concentrations: A Critical Analysis of Viability. International Journal of Greenhouse Gas Control, 3, 757-767. http://dx.doi.org/10.1016/j.ijggc.2009.07.001

[10] Schuiling, R.D. and de Boer, P.L. (2013) Six Commercially Viable Ways to Remove $\mathrm{CO}_{2}$ from the Atmosphere and/or Reduce $\mathrm{CO}_{2}$ Emissions. Environmental Sciences Europe, 25, 35. 